\title{
Money And Its Effect On U.S. Housing Sub-Markets: Evidence From The VAR Model
}

Doh-Khul Kim, (E-mail:dkim@meridian.msstate.edu), Mississippi State University

\begin{abstract}
Even though it is an area worth studying for policymakers, little research has in fact been done to observe differential effects of monetary policy on housing sub-markets; i.e., new home construction and existing home sales. Utilizing a vector autoregression (VAR) framework, this paper explores the response differentials across the two housing sub-markets in the short run. According to findings in this research, in the short run, the existing home sale market is relatively more affected by expansionary monetary policies than is the new home construction market. Thus, it is suggested policymakers should provide more motivating policies for both builders and consumers to encourage more economic activities in the new home construction market.
\end{abstract}

\section{INTRODUCTION}

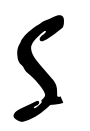

ince 2001 the Federal Reserve System in the U.S. has adopted aggressive expansionary monetary policies in an effort to stimulate the sluggish U.S. economy and get it back on a normal track. As a result of these policies interest rates (including federal funds rate) have fallen to their lowest level in the U.S. in more than 40 years. Both consumers and producers can lower their borrowing costs and increase their expenditures in both consumption and investment by taking advantage of these low interest rates (financial wealth). Therefore, most of the industries are expected to be positively affected by such expansionary monetary policies in the economy. One of the industries expected to be affected substantially by the interest rate movements is the durable-good producing sector, with the housing market being one key representative of this sector (sub-industry) which will be sensitive to the movements in the interest rate (Muellbauer and Murphy, 1997; Kasparova and White, 2001; Fratantoni and Schuh, 2003).

Thus far numerous papers have studied the responses and interactions between the housing market variables (i.e., demand, supply and price) and economic (fiscal and monetary) policy changes, with the general consensus being the overall housing market is positively affected by the expansionary monetary policies (Kau and Keenan, 1980; Wheeler and Chowdhury, 1993; Rahman and Mustafa, 1997; Coulson and Kim, 2000; Ahmed and Dua, 2001; Capozza and Li, 2001; Lastrapes, 2002; Davis and Heathcote, 2004). However, not much research has involved studying the interactions between housing sub-markets (new home construction and existing home sales) and monetary policies even though the size of the responses to the policy changes may differ across the two sub-markets.

Proper identification of this response differential would be valuable to many economic agents and economic policymakers including housing market agents. Greater increases in new home construction in response to the expansionary policies as compared to existing home sales will lead to larger infusions to employment and total GDP as new home construction induces relatively more construction activities. Furthermore, it will cause less inflationary pressure on the housing market as any higher housing demand will be satisfied by those new home construction activities. In contrast, if expansionary monetary policies affect existing home sales more than new home construction, relatively fewer construction activities and lower employment are expected with higher inflationary pressure.

The main purpose of this paper is to research the response differentials in the short run between new home construction and existing home sales when an expansionary monetary policy is in effect. To this end, based on data 
from the U.S. this study utilizes a popular time-series tool; vector autoregression (VAR) framework that has been widely adopted in recent time-series research thanks to its allowing an easier identification of variables of interest without any concern about endogeneity problems. For proper identification of the response differentials using the VAR, a multivariate cointegration procedure proposed by Johansen (1988) and Johansen and Juselius (1990) is first used to determine if there is any long-run equilibrium relationship present among the two housing sub-markets and the monetary policy. The VAR models are then used to identify the magnitude of the short-run responses in both new home construction and existing home sales to the expansionary monetary policy in the economy.

This paper finds that in the short run, the existing home sale market is more responsive to expansionary monetary policies than is the new home construction market. Therefore, it can be inferred that in the short run, expansionary monetary policies will induce relatively fewer economic activities and lower employment with greater inflationary pressures in the housing market. This paper discusses the empirical analysis and the results in Section II, and the conclusion and policy implications in Section III.

\section{EMPIRICAL METHODOLOGIES}

\section{Data}

The quarterly data (from 1970 to 2004) used in this study were obtained from the U.S. Census Bureau and Bureau of Economic Analysis. They represent the total residential structures investment and new home construction, from which the data for existing home sales are then derived by differencing new home construction from the total residential structure investment. The money supply (M1 and M2) and interest rate data were obtained from the Federal Reserve Bank of St. Louis. The specific interest rate variable used is the long-term interest rate from 1970 to 2004. ${ }^{1}$ Using an augmented Dickey-Fuller test (1981), all the variables are found to have unit roots in their level-form, but all are stationary in their first-difference form (Table 1). ${ }^{2}$ Thus, the cointegration test can be performed as all variables have single unit roots and are cointegrated in the same order, $I(1)$.

\section{Table 1: Augmented Dickey-Fuller Test}

\begin{tabular}{|c|c|c|}
\hline Interest Rate & New Home Construction & Existing Home Sale \\
\hline-1.74 & -1.12 & -1.69 \\
$(-5.39)$ & $(-12.71)$ & $(-6.14)$ \\
\hline
\end{tabular}

Notes: The numbers in parenthesis indicate t-statistics for the first differenced variables and they all reject the null hypothesis of the unit root, whereas the numbers in the upper row accept the hypothesis at $5 \%$ significance level. Thus, all the variables are non-stationary in levels and have the same single unit roots, $I(1)$.

The lag lengths and the most parsimonious models with no autocorrelation for the variables are chosen following the results of Akaike's Information Criterion (AIC) and Schwartz Bayesian Criterion (SBC) tests.

\section{Cointegration Test}

The cointegration test is performed first because the results from that test will be used for the VAR analysis that follows. This cointegration test makes all of the variables explicitly endogenous with the results being constant with respect to the direction of normalization. The variables adopted in this cointegration test are the two housing submarket variables and the long-term interest rate.

\footnotetext{
${ }^{1}$ This paper uses the long-term government bond rate as the conventional mortgage rate is more affected by the long-term interest rate. However, the federal funds rate and the 5-year Treasury note are also employed, respectively, for the robustness of the findings. In addition, no qualitatively different result is found in this research.

${ }^{2}$ The Phillips-Perron test shows the same result for the variables under investigation.
} 
Table 2: Results of Johansen Maximum Likelihood Estimation

$\lambda_{\text {trace }}$ Test

\begin{tabular}{|c|c|c|c|}
\hline Null Hypothesis & Alternative Hypothesis & $\mathbf{9 5 \%}$ Critical Value & $\lambda_{\text {trace }}$ Value \\
\hline$r=0$ & $r>0$ & 29.68 & $73.60^{*}$ \\
\hline$r \leq 1$ & $r>1$ & 15.41 & 9.74 \\
\hline$r \leq 2$ & $r>2$ & 3.76 & 2.80 \\
\hline
\end{tabular}

$\lambda_{\max }$ Test
\begin{tabular}{|c|c|c|c|}
\hline Null Hypothesis & Alternative Hypothesis & $\mathbf{9 5 \%}$ Critical Value & $\lambda_{\max }$ Value \\
\hline$r=0$ & $r=1$ & 20.97 & $63.86^{*}$ \\
\hline$r=1$ & $r=2$ & 14.07 & 6.94 \\
\hline
\end{tabular}

Notes: * denotes significance at the 5\% level. $r$ denotes the number of cointegrating vectors and the $5 \%$ critical values of the maximum eigenvalue and the trace statistics are obtained from Enders' RATS Handbook (1996).

A cointegrating vector implies a long-run equilibrium relationship among the endogenous variables. More cointegrating vectors in the system imply more stability of the system which is composed of the non-stationary variables. According to Table 2, the value of 73.60 is greater than the $95 \%$ critical value of the $\lambda_{\text {trace }}$ statistic (29.68) as shown in the first panel. ${ }^{3}$ Hence, the null hypothesis of no cointegrating vectors is clearly rejected and the alternative hypothesis of one or more cointegrating vectors is accepted. Next the $\lambda_{\text {trace }}(1)$ statistic is applied to test the null of $\boldsymbol{r} \leq 1$ against the alternative of two or three cointegrating vectors. The null hypothesis is not rejected this time as the $\lambda_{\text {trace }}(1)$ statistic of 9.74 is less than the $95 \%$ critical value of 15.41 . Therefore, one cointegrating vector is said to be present among the variables.

Applying the $\lambda_{\max }$ statistic, the null hypothesis of no cointegrating vectors $(\boldsymbol{r}=0)$ against the specific alternative $\boldsymbol{r}=1$ is rejected because the calculated value $\lambda_{\text {max }}(0,1)=63.86$ exceeds the $95 \%$ critical value (20.97). Testing $\boldsymbol{r}=1$ against the alternative of $\boldsymbol{r}=2$, the calculated value of $\lambda_{\max }(1,2)$ is 6.94 , whereas the critical value at the 95\% significance level is 14.07. Therefore, there is one cointegrating vector present because the test $\boldsymbol{r}=1$ against $\boldsymbol{r}$ $=2$ is not rejected. Hence, it can be claimed there is a long-run relationship present among the variables of interest following the results of both tests in the U.S. housing market.

\section{Cointegrating Vector}

Table 3: Normalized Cointegrating Vector

\begin{tabular}{|c|c|c|}
\hline New Home & Interest Rate & Existing Home \\
\hline 1.000 & -4.13 & 0.37 \\
\hline Existing Home & Interest Rate & New Home \\
\hline 1.000 & -12.19 & 3.87 \\
\hline
\end{tabular}

Notes: The cointegrating vector is normalized with respect to new home and existing home sales, respectively. The signs of all the coefficients are consistent with general expectations.

\footnotetext{
${ }^{3}$ To conserve space, the cointegration model is not described here as Johansen (1988) and Johansen and Juselius (1990) provide a detailed description of the test procedure.
} 
Table 3 shows the values of the coefficients of the cointegrating vector that will be incorporated into the following VAR model. The vector does make economic sense as long as the estimated coefficients have the same sign as those predicted by economic theory. All the coefficients in Table 3 are consistent with theoretical predictions and the findings of most empirical studies. ${ }^{4}$ However, according to Dickey et al. (1991), the coefficients do not provide any structural interpretations regarding the magnitude of the parameters of the cointegrating vectors. Instead the cointegrating vectors simply imply long-run and stable relationships among the endogenous variables.

\section{Vector Autoregression (VAR) Framework (Short-Run Dynamics)}

In order to see the short-run responses of the two variables (new and existing home sales) and their relative sizes, the two variables are re-estimated by utilizing a VAR framework with the cointegrating relationship properly incorporated. A 3-variable (new or existing home sales, interest rate and nominal money supply) model is built for each sub-market. Let, $Y_{t}=\left(\begin{array}{c}\Delta h_{t} \\ \Delta R_{t} \\ \Delta M_{t}\end{array}\right)$, where $h_{t}$ is new or existing home sales, $R_{t}$ is a nominal interest rate and

$M_{t}$ is a nominal stock of money. ${ }^{5}$ The basic structural VAR model can be expressed as follows;

$A_{0} Y_{t}=A_{1} Y_{t-1}+A_{2} Y_{t-2}+\ldots .+A_{p} Y_{t-p}+u_{t}$

where, $\boldsymbol{u}_{t}$ is a $3 \times 1$ vector of mutually uncorrelated white-noise disturbances, with one of the $\boldsymbol{u}_{t}$ variables measuring money supply innovations. All the variables are differenced once to impose stationarity, which is a valid transformation as all the elements of $Y_{t}$ have single unit roots. Because equation (1) is a structural VAR, it cannot be directly estimated due to the correlation between the independent variables and $\boldsymbol{u}_{t}$. The model to be estimated, using OLS, is the reduced VAR representation that follows:

$Y_{t}=B_{1} Y_{t-1}+B_{2} Y_{t-2}+\ldots+B_{p} Y_{t-p}+\varepsilon_{t}$

where, $B_{t}=A_{0}^{-1} A_{t}, \varepsilon_{t}=A_{0}^{-1} u_{t}$, and $E \varepsilon_{t} \varepsilon_{t}^{\prime}=\sum=A_{0}^{-1} A_{0}^{-1^{\prime}}$.

However, the structural coefficients in equations (1) cannot all be recovered from the estimation without further restrictions on the structural system, because a mapping from the structural system (equation 1) to the reduced form (equation 2) is not unique. The restriction employed here is the long-run monetary neutrality that is widely accepted in recent VAR models. Such a long-run neutrality hypothesis has the restriction that nominal shocks such as a money supply shock have no permanent effect on the levels of the real variables. ${ }^{6}$

With the models in equation (1) and (2) appropriately estimated, accumulated impulse responses (in figures) can be obtained. ${ }^{7}$ Figure 1 shows the responses of both new home construction and existing home sales to an expansionary monetary policy (or shock) in the economy. From Figure 1, in the short run existing home sales can be seen as more sensitive to the shock than new home construction as the response of the existing home sales has a greater magnitude. ${ }^{8}$

\footnotetext{
${ }^{4}$ Refer to Kasparova and White (2001) (pp. 400-401) for a discussion of in-depth theoretical relationships among the variables and policy changes.

${ }_{6}^{5}$ Both M1 and M2 are used for this variable with the results being similar across the two categories. Hence, the findings are robust to the categories.

${ }^{6}$ The use of restrictions at the infinite horizon was pioneered by Shapiro and Watson (1988) and Blanchard and Quah (1989). It is extensively used in VAR literature with regards to aggregate macroeconomic activities.

${ }^{7}$ Once again, the cointegrating relationship is properly taken into account by adding the error-correction term into the VAR model.

${ }^{8}$ The figure shows the responses using M1; responses with M2 are not reported here as there is no qualitative difference between the two categories.
} 
Table 4: Impulse Responses to Monetary Shocks

\begin{tabular}{|c|c|c|}
\hline Quarter(s) & New Home Construction & Existing Home Sales \\
\hline 1 & 0.054 & 0.377 \\
2 & 0.207 & 0.676 \\
3 & 0.423 & 1.003 \\
4 & 0.523 & 1.104 \\
5 & 0.553 & 0.951 \\
6 & 0.347 & 0.758 \\
7 & 0.224 & 0.441 \\
8 & 0.131 & 0.278 \\
\hline
\end{tabular}

Table 4 shows the responses of each sub-market to the monetary shock for eight quarters. For every one unit of monetary shock, there is a 0.054 unit change in new home construction and a 0.377 unit change in existing home sales in the first quarter after the shock was induced. The response of new home construction peaks at 0.553 during the $5^{\text {th }}$ quarter after the shock, while that of existing home sales peaks at 1.104 during the $4^{\text {th }}$ quarter after the shock. Thus, the responses of existing home sales are once again greater in magnitude than those of new home construction.

\section{CONCLUSION}

As numerous empirical research studies have shown the responses of the housing market to policy changes in the economy, it is generally accepted the housing market is positively affected by any expansionary monetary policies. However, even though policymakers and housing market agents could obtain valuable insights from the information, there are only a few studies that show how such policies affect housing sub-markets differently. This paper shows the expansionary monetary policies in the short run affect the existing housing market more substantially than the new home construction market. Hence, in the short run, the expansionary monetary policy will be less effective in affecting economic activities and employment with greater inflationary pressures in the housing market. As a result, it is recommended policymakers should provide more effective economic benefits for both builders and potential consumers to induce more economic activities in new home construction.

\section{Acknowledgements}

An earlier version of this paper was presented at the 2004 International Business and Economics Research Conference in Las Vegas (October). The author would like to thank the conference participants for their valuable comments and suggestions. All remaining errors are attributed to the author.

\section{REFERENCES}

1. Ahmed, H., and P. Dua. 2001. Effects of Monetary Variables on Real Output: Sensitivity Analysis. Applied Economics Letters 8: 65-69.

2. Bernanke, B. S., and I. Mihov. 1998. Measuring Monetary Policy. Quarterly Journal of Economics 113: 869-902.

3. Blanchard, O. J., and D. Quah. 1989. The Dynamic Effects of Aggregate Demand and Supply Disturbances. American Economic Review 79: 655-73.

4. Capozza, D., Y. Li. 2001. Residential Investment and Interest Rates: An Empirical Test of Land Development as a Real Option. Real Estate Economics 29: 503-19.

5. Christiano, L. J., M. Eichenbaum, and C. L. Evans. 1997. Sticky Price and Limited Participation Models of Money: A Comparison. European Economic Review 41: 1201-49.

6. Coulson, N. E., and M-S. Kim. 2000. Residential Investment, Non-residential Investment and GDP. Real Estate Economics 28: 233 - 47.

7. Davis, M., and J. Heathcote. 2004. Housing and the Business Cycle. Board of Governors of the Federal Reserve System (U.S.), Finance and Economics Discussion Series: 2004-11. 
8. Dickey, D. A., and W. A. Fuller. 1981. Likelihood Ratio Statistics for Autoregressive Time Series with a Unit Root. Econometrica 49: 1057-72.

9. Dickey, D., D. Jansen, and D. Thornton. 1991. A Primer on Cointegration with an Application to Money and Income. Review of Federal Reserve Bank of St. Louis 73: 58-78.

10. Enders, W. 1995. Applied Econometric Time Series, John Wiley \& Sons, Inc.

11. Enders, W. 1996. RATS Handbook for Econometric Time Series, John Wiley \& Sons, Inc.

12. Engle, R. F., and C. W. J. Granger. 1987. Cointegration and Error Correction: Representation, Estimation, and Testing." Econometrica 55: 251-76.

13. Fratantoni, M., and S. Schuh. 2003. Monetary Policy, Housing, and Heterogenous Regional Markets. Journal of Money, Credit, and Banking 35: 557-89.

14. Granger, C. W. J. 1969. Investigating Causal Relationships by Econometric Models and Cross Spectral Models. Econometrica 37: 424-38.

15. Johansen, S. 1988. Statistical Analysis of Cointegration Vectors. Journal of Economic Dynamics and Control 12: 231-54.

16. Johansen, S., and K. Juselius. 1990. Maximum Likelihood Estimation and Inference on Cointegration - with Applications to the Demand for Money. Oxford Bulletin of Economic and Statistics 52: 169-210.

17. Kasparova, D., and M. White. 2001. The Responsiveness of House Prices to Macroeconomic Forces: A Cross-country Comparison. European Journal of Housing Policy 1: 385-416.

18. Kau, J. B., and D. Keenan. 1980. The Theory of Housing and Interest Rates. Journal of Financial and Quantitative Analysis 15: 833-47.

19. Lastrapes, W. 2002. The Real Price of Housing and Money Supply Shock: Time-series Evidence and Theoretical Simulations. Journal of Housing Economics 11: 40-74.

20. Muellbauer, J., and A. Murphy. 1997. Booms and Busts in the UK Housing Market. The Economic Journal 107: 1701-27.

21. Rahman, M., and M. Mustafa. 1997. Growths in US Housing Starts, Real Consumer Debt, Real GDP and the Long-term Real Interest Rate: A Vector Cointegration Analysis. Applied Economics Letters 4: 757-59.

22. Shappiro, M., and M. Watson. 1988. Sources of Business Cycle Fluctuations. In Stanley Fisher, editor, NBER Macroeconomics Annual, Cambridge: MIT Press: 111-48.

23. Wheeler, M., and A. R. Chowdhury. 1993. The Housing Market, Macroeconomic Activity and Financial Innovation: An Empirical Analysis of U.S. Data, Applied Economics 25: 1385-92.

24. White, H. 1980. A Heteroskedasticity - Consistent Covariance Matrix and a Direct Test for Heteroskedasticity. Econometrica 48: 721-46. 